\title{
Music Industry Intermediation in the Digital Era and the Resilience of the Majors' Oligopoly: The Role of Transactional Capability
}

\author{
Rémy GUICHARDAZ, Laurent BACH, Julien PENIN
}

\author{
University of Strasbourg, CNRS
}

BETA UMR 7522

F-67000 Strasbourg, France

Corresponding author: rguichardaz@unistra.fr

\begin{abstract}
The digital revolution has significantly impacted on the traditional business model of the music industry by lowering barriers to market entry. This change is usually depicted as a throwback to the past in which artists have more control and autonomy in the business thanks to a new range of online intermediaries that challenge the big incumbent firms, the so-called "Majors" (Universal, Sony, and Warner). This paper argues that this diagnosis is incomplete and does not take into account the recent changes that the Majors have successfully implemented into their business model. Based on a case study of the French arm of Sony Music Entertainment, the paper shows how and why the Majors are still playing a competitive intermediary role thanks to the development of transactional capabilities.

Keywords: music industry; disintermediation; dynamic capabilities; transactional capability; business model
\end{abstract}

Classification-JEL: L82, L22, O33 


\section{Introduction}

The traditional music industry is characterized by an oligopolistic market structure in which the majority of the market share belongs to big firms (the so-called "Majors"), while the rest of the market is divided between independent labels (Caves, 2000; Gander et al. 2007; Lebrun, 2006) ${ }^{1}$. During the 2000s, a large section of the literature within economics and management stressed the fact that this traditional market structure was undergoing brutal and significant changes through the introduction of illegal newcomers, followed by legal ones, which both used the internet as a subversive tool to distribute music (Alexander, 2002; Casadesus-Masanell \& Hervas-Drane, 2008; Rupp \& Estier, 2002).

Beyond the piracy phenomenon, these studies show the very attractive aspect for consumers to use this decentralized distribution system compared with the traditional system of intermediation. Thanks to digital technologies, supply and demand can now meet each other without the institutional limitations of record labels' policies (Sen, 2010; Bernardo, 2013; Benkler, 2006). On one side, artists can create music in a home studio at a very low cost while promoting and distributing their products online; and on the other side, music listeners and fans benefit from millions of songs, interact with artists, and even sometime fund their projects via social networking services (Barbier et al. 2008; Bernardo, 2013; Hracs, 2012; Leyshon, 2009; Sen, 2010; Winter, 2012).

This paper claims that such a diagnosis is misleading and does not explain the recent evolution of the music industry, which remains dominated by the Majors' oligopoly. Basing our argument on the notion of "transactional capability" (which we define later in the article) and relying on the case study of Sony Music Entertainment France, we show that the Majors continued to play a proactive role in the music industry, at least until the latter's downturn in 2015 , by transforming their structure and expertise. In doing so, our contribution fulfills a significant gap in the literature, which tends to insist on the decline of these traditional intermediaries.

Indeed, an enthusiastic strand of the literature has shown how the flexibility of new intermediaries might opportunistically supplant the very selective and centralized gatekeeping procedure of the Majors (Ordanini et al. 2009; Bernardo, 2013). This idea has been depicted through several concepts such as "Do It Yourself" artists and "Prosumers" - fans for whom independent music is the most logical production model. These authors conclude that Majors will no longer dominate the sector and are doomed to evolve in a much more atomistic and fragmented market, as experienced by the studios and the sound engineering sector a decade earlier (Leyshon, 2009). In this context, "independent" or "smaller" artists would be more

\footnotetext{
${ }^{1}$ This oligopolistic structure can be explained by both the cost structure working within the industry and the specific nature of the music product (Nelson, 1970), which encourages Majors to be vertically integrated along the value chain in order to avoid opportunistic behaviors between economic agents (Williamson, 1985). The internalization of the double marginalization and the huge fixed cost of the distribution network allow integrated firms to be more efficient while regulating competitive pressure (Alexander, 1994; Krattenmaker \& Salop, 1986). Ultimately, the growing number of music releases resulting from this competitive advantage drives the Majors to saturate prescriptive channels and prevent the rise of independent labels to cover their own products (Alexander, 1994; Curien \& Moreau, 2006).
} 
visible and successful and would challenge the star-system by imposing greater diversity (Anderson, 2004; Sen, 2010; Bernardo, 2013).

Put another way, this strand of the literature broadly follows the seminal work of Chircu \& Kauffman (1999) on electronic markets, arguing that the internet conducts an intermediation, disintermediation, and reintermediation (IDR) cycle whereby new kinds of intermediary replace the old ones. Some evidence suggests that this cycle process can be applied to the traditional music industry actors. The most obvious example is the Majors' drastic fall in revenue from record sales. Waldfogel (2012) observes that worldwide revenue from physical recorded music fell from US\$37 billon to US\$25 billion from 1999 to 2007. This brutal drop impacted negatively on the intermediary functions of the Majors: they decreased their artist portfolio by 30 percent, focusing on the less risky segments of the market (Wikström, 2009). In France, the number of new contracts signed fell by 51 percent between 2002 and 2009, while marketing investment decreased by 56 percent (Source: SNEP, 2010).

Another strand of the literature has explained the severity of this decline by highlighting the existence of cognitive bias in the Majors as they face disruptive effects (Blanc \& Hault, 2010; Moyon \& Lecoq, 2007). Because of deeply rooted routines inherited from the past, the Majors were not able to evolve into the digital era. They first tried to counter the disruptive effects of digitalization and then to replicate their traditional business model online (Beuscart, 2007; Blanc \& Hault, 2010). The most recent contributions to this literature have noted how difficult it was, at least initially, for the Majors to shift towards a new business model called the "360-deal strategy", which relies on the synergistic relationship between a growing number of sectors, businesses, and projects (Moyon \& Lecoq, 2007; Marshall, 2013; Moyon \& Lecoq, 2013).

However, these works do not provide any explanation of how this new business model is actually performed by the Majors and why they are still dominating the intermediate functions of the music market. Indeed, although they were the very first intermediaries to experience the impact of digital technologies, Universal, Sony, and Warner still held around 73.2 percent of the worldwide revenue market share in 2015. This domination is also visible in music publishing, in which the three Majors held 63.8 percent of the market in $2015^{2}$.

Consequently, our main objective is to stress how the Majors are able to continue as an oligopoly in the "old physical" music market, which is constantly decreasing, but also in the overall music market, which is now growing again. We contend that the Majors have managed to reorganize themselves and redefine their frontiers and environment in a way that increases their ability to sell and buy many products in the best conditions, by developing their own 360-deal strategy. At the same time, the competitive advantage of indie labels, characterized by the "creative efforts" of new music styles (Caves, 2000; Gander, 2007), is less able to capture the complex economic value of music in the digital era. Furthermore, we show that this adapted form of the 360-deal strategy requires much more interaction with

\footnotetext{
${ }^{2}$ Music and Copyright https://musicandcopyright.wordpress.com/tag/market-share/, last consultation 27/10/2016
} 
external actors than before. In this context, we argue that transactional capability, that is to say capability which increases market exchange between a firm and its environment, constitutes a key asset in implementing such a business model. Indeed, transactional capability, thanks to the renewal of specific historical resources and recent strategic changes, is becoming predominant among music Majors and can provide a good explanation for their resilience.

In the next section, we analyze the role of market intermediaries in light of transaction cost theory and resource-based view theory. This leads us to focus on the notion oftransactional capability. In the following two sections, we present the case of Sony Music Entertainment France. We explore how this Major has been able to reorganize in order to implement a new strategy to capture revenue from an evolving market, and how transactional capability plays a key role in this evolution. Section 3 details the methodology used, and section 4 presents the main results of this case. Section 5 concludes.

\section{Market Intermediation}

\subsection{Reconciling TCT and KBV Theories: The Role of Transactional Capability}

Economic exchanges have always required a structure to play the role of intermediary between economic agents. From an historical point of view, this phenomenon has taken many forms - from wholesaler, broker, or retailer to procurement platform and online interface. In this regard, internet expansion has increased the diversity of these agents of different shapes and sizes. This diversity is also visible in the various economic theories which try to explain the phenomenon.

As a first approach, transaction cost theory (TCT), considers the intermediation process as a means of reducing the cost of using market mechanisms. Indeed, according to Coase (1937), the market generates transaction costs. These transaction costs depend mostly on the properties of transactions (which, it should be noted, are largely exogenous) and have been shown to be key in explaining organizations" "make or buy" decisions (Williamson, 1975, 1985; Riordan \& Williamson, 1985).

From this perspective, intermediaries simply exist because of their ability to reduce opportunistic behaviors or hazard issues through contractual arrangements (depending mainly on the specificity and frequency of the product exchanged). Theoretically, according to TCT, there is no need for the intermediate firm to have any practical expertise in performing its intermediary role. The simple presence of a neutral intermediary between supply and demand suffices to resolve transactional issues (Williamson, 1985). For instance, the mere existence of a third party will often be sufficient to avoid free-riding behaviors from one side of the market even if this third party does nothing more than simply being present. 
In contrast, the resource-based view (RBV) of the firm explains the competitive advantage of firms through the heterogeneity of their resources (Penrose, 1959; Selznick, 1957; Becker, 1962; Barney, 1991). According to RBV, firms own different sets of resources but also different abilities to use these resources efficiently. More recently, the knowledgebased view (KBV) of the firm has stressed the fundamental role of knowledge creation in explaining a firm's success. Such intangible assets are strategic inputs in arranging the technological and productive resources of the firm into new products and solutions. According to $\mathrm{KBV}$, intermediation is thus explained by the fact that certain firms have specific and valuable capabilities for the parties involved in the exchange. The firm, thanks to this specific endowment, performs its intermediary role by adding economic value to the transaction.

Presented in this manner, KBV and TCT appear fairly incompatible. This opposition is sometimes accentuated by the fact that KBV literature conceptualized capabilities without any consideration of external actors: technological capability (Katz, 1984; Lall, 1992; Patel \& Pavitt, 1997), operational capability (Miller \& Roth 1994; Skinner, 1969), core capability (Prahalad \& Hamel, 1990), managerial capability (Du Gay et al., 1996; Stamp, 1981), and organizational capability (Chandler, 1992; Zander \& Kogut, 1995) focus primarily on the firm's internal issues. Furthermore, as we have already mentioned, TCT focuses primarily on elements which are external to the firm, and sees transaction costs as being exogenous, in other words, as largely unaffected by firms' decisions and resources. More precisely, for a given level of the three key variables (frequency, specificity, and uncertainty), firms are supposed to be all subject to the same level of transaction costs.

However, some contributions suggest that KBV and TCT should be integrated and considered as complementary. In fact, several efforts have been made to articulate these two perspectives (Argyres \& Liebeskind, 1999; Cohendet \& Llerena, 2005, Jacobides \& Winter, 2005; Langlois \& Foss, 1999; Poppo \& Zenger, 2002; Williamson, 1999; Zawislak et al., 2012). Amit \& Zott (2005) suggest that resources can be divided into "activity-enabling resources" linked to the core of the firm's activity and "transaction-enabling resources" linked to interaction with the market. Although Amit \& Zott focus only on the former (activity-enabling), they suggest that "transaction-enabling resources" modify the governance choice of the firm, since a "focal firm's endowment with such resources may matter, regardless of their degree of firm-specificity" (p. 33). More recently the work of Tello-Gamarra \& Zawislak (2013) has proposed the concept of "transactional capability" as a bridge between the TCT and KBV perspectives. Transactional capability is "a repertoire of abilities, processes, experiences, skills, knowledge and routines that the firm uses to minimize its transaction costs (ex-ante and ex-post)" (p. 1).

Teece, Pisano \& Shuen (1997) also mention the existence of relational and reputational assets that structure a firm's relationship with customers, suppliers, and competitors. In line with this first insight, other scholars have provided a growing understanding of how a firm captures relational rent from alliances in a changing environment (Dyer and Kale, 2007; Dyer and Singh, 1998; Eisenhardt and Martin, 2000; Kale et al., 2002). Recent works have shown that such assets facilitate coordination and bonding (Schreiner et 
al., 2009; Schilke, 2014) through specific social governance mechanisms (Van der MeerKooistra \& Vosselman, 2000), lowering costs between partners (Dyer and Kale, 2007). This research has been grouped under the generic name of "relational dynamic capability" (Donada et al. 2016). The manifestation of such capabilities can be embodied by routines, procedures, and governance schemes.

Following the same dynamic perspective, we define transactional capability as a set of routines, resources, governance schemes, and skills that allows a firm to perform intermediation functions, and dynamic transactional capabilities such as the ability to create and reconfigure them in a changing environment. As such, transactional capability does not focus exclusively on a firm's properties but also on the market intermediation process between its partners and customers to capture a relational rent. These factors are driven mainly by transaction cost aspects that can be moderated by the transactional capability of the firm. Indeed, knowing how to manage market interactions involves specific skills including the ability to choose the right partners/clients, a relevant governance structure, and the right relational standards (involving flexibility, customization, long-term view, information sharing, and so on).

In other words, transaction costs are not exogenous and can be modified and transformed by the development of transactional capability. This knowledge is not easy to obtain and sustain (Ireland et al., 2002). One of the most important rationales for music Majors' intermediation therefore lies in their ability to manage transactional capability, as we will now see.

\subsection{The Case of Music Market Intermediation}

A pure TCT framework cannot explain the current situation of the music industry, in which the Majors have continued to play a key role as economic intermediaries. The internet has been generating a global lowering of entry for intermediation functions in the music market with the emergence of a new set of firms (aggregators, online labels, specialized social networks, crowdfunding platforms, etc.) which propose to commercialize and distribute music content all around the world at very low cost. Given the decrease in transaction costs in the music market, focusing solely on this aspect would naturally lead us to conclude that intermediaries in the form of the Majors are doomed to disappear.

KBV theories suggest that the Majors' intermediation persists because they create direct economic value in music content by providing engineering skills, specific recording facilities, musician assistance, and so on. Though these assets are still important today in the industry, digitalization has considerably democratized access to technology supports. The merger of audio systems with computing devices has turned music into an information product whereby the artist can work and mix at very low cost. The strategic aspect (Barney, 1991) of the engineering and recording studio sector has been declining with digitalization (Leyshon, 2009). In other words, the core strengths of the Majors, including production distribution and promotion tasks, are easier to replicate today thanks to digital intermediation and provide a means of empowerment for both artists and fans (Barbier et al. 2008; Bernardo, 
2013; Hracs, 2012; Leyshon, 2009; Sen, 2010; Winter, 2012). And so, when relying uniquely on a KBV understanding of the music market, the natural conclusion is once again that the Majors are doomed to disappear given the decreasing importance of the assets that were behind their key role in the "old world".

The focus on transactional capability can provide a convincing explanation for the resilience of the Majors. But this must be understood in the perspective of an evolution of the Majors' strategy in answer to the changing environment. In fact, while the internet has vastly multiplied the possibilities of the creation and distribution of music, it has also made it incredibly difficult to capture economic value from music activities. In particular, sources of revenue are now multiple. Record companies have then considerably changed their monoproduct value proposal, as we stressed in our introduction. Music is now a multifaceted artifact which is offered in the form of many different goods, leading to the adoption of a new business model.

This strategy implies that label and artist share every type of income stream connected to music production: recordings, live performance, merchandising, sponsorship, endorsements, etc. These resources are heterogeneously distributed across numerous different actors that are not always related to record companies. In this sense, the new music business era is much more difficult to conduct than it was before, which increases the complexity of the intermediation process in the music market. Consequently, there is room for intermediaries who play a proactive role in making deals in the market. In this context, we may suggest that transactional capability constitutes a key factor in building a sustainable music business through long-term and profitable deals.

Furthermore, not only has the new situation increased the importance of transactional capability, but it may also change the organization of the music Majors, which was traditionally vertically integrated. Indeed, during the traditional era of the music industry, production, promotion, and distribution were sequentially implemented. In this model, the industrialization of the product was driven by different stages: the first stage involved production of the music content; the second stage involved physical support of the content; and the final stage was to market and distribute the product through an in-house distribution system and other forms of traditional music diffusion (such as radio and concerts) which supported this main distribution channel. Except for final retailers, the entire value chain of the industry was monitored by the managerial structure of the Majors.

This strong integration can be explained by transaction costs consideration: the high specificity of music investment induces producers to control distribution and development tasks to avoid opportunistic behaviors and bargaining charges (Curien and Moreau, 2006). However, this type of linear structure requires a constant flow of information to switch from one stage to another. Vertical coordination was precisely possible because of the relative simplicity of the value proposal of the industry, whereby demand was merely met according to a mono-product strategy (vinyl then CD-ROM).

Yet this structure is no longer tenable in the current music industry. To handle the complexity of their environment, Majors must create an extensive intermediation strategy that 
relies on a large variety of skills and actors that goes beyond their core strengths. Such a production process is costly in terms of coordination and transaction. Complexity therefore encourages record companies to change their routines and organizational structures towards a much more reactive scheme.

We will now present the case study conducted in order to analyze how the Majors have managed to keep their key intermediation role in the music industry while changing their strategy and organization; in particular, we explore the role and nature of the transactional capabilities developed by the Majors and their close interactions with these changes.

\section{Sony Music Entertainment France: Case Study Methodology}

\subsection{Methodology Justification and Delimitation}

This empirical study is based on a rigorous protocol that conforms to the recommendations of the literature (Albarello, 2011; Eisenhardt, 1989; Yin, 2003). Among the main guidelines mentioned in these works, transparency constitutes a key element of the scientific validation of such an approach. In this regard, this section details how the study was constructed, and guarantees the validity of the results (Yin, 2003).

Our qualitative approach is motivated by the nature of our research program, which requires a comprehensive approach, insisting on the social and contextual dimensions of the firm which can only be revealed using qualitative steps going "beyond methods with which we are comfortable and confident" (Barney et al., 2001, p. 637). Moreover, as Yin (2003) has underlined, qualitative methods are particularly suited to the exploration of new phenomena such as the impact of the technology breakthrough on economic actors. The significant changes that the industry continues to undergo today have thus been determinant in our choice of method.

The study focuses on the transformation of Sony Music Entertainment over the recent period 2009-2014. In taking this timeframe into account, our aim is to acknowledge the proposals of Yin (2003) and Eisenhardt (1989), who have stressed the importance of context in the study and understanding of recent phenomena. We have also extended our analysis to the immediate environment of Sony Music by studying three levels of actor surrounding the firm: competitors; other activities in the music business such as music publishing, concerts etc.; and related industries such as online retailers and other creative sectors. In order to better understand the ability of the Major to maintain its rank in this complex environment, we provide a greater focus on independent competitors by comparing their resources and capabilities with those of Sony Music. 
The diversity of the data collection also allows a consolidation of the external validity of the results (Yin, 2003). Indeed, the choice of independent labels considered in our study is driven by their heterogeneity (cf. Table 1). As we will see further on, parameters such as size, market positioning, and distribution assets are crucial to understand the development of transactional capability in the different actors of the industry. We also increased the internal validity of our results by drawing on a diverse range of sources connected to Sony Music Entertainment. In particular, we focused on the link between one of the most important labels of the Major that we renamed Sony-label for reasons of confidentiality, and the transversal services of the Major that are directly monitored by its managerial structure.

Table 1: Main characteristics of the different firms considered in the case study

\begin{tabular}{|c|c|c|c|c|c|}
\hline Label code & $\begin{array}{l}\text { Distribution } \\
\text { system }\end{array}$ & $\begin{array}{l}\text { Sales } \\
\text { revenue } \\
\text { in } 2014\end{array}$ & $\begin{array}{l}\text { Approximate } \\
\text { Number of } \\
\text { employees }\end{array}$ & Market position & $\begin{array}{l}\text { Geographical } \\
\text { reach }\end{array}$ \\
\hline Sony-label & $\begin{array}{l}\text { Sony Music } \\
\text { Entertainment } \\
\text { France }\end{array}$ & $€ 80$ million & 190 & General & International \\
\hline Indie-label 1 & Warner & $€ 3$ million & 30 & Variety/Pop & France and UK \\
\hline Indie-label 2 & $\begin{array}{l}\text { Self- } \\
\text { distributed }\end{array}$ & $€ 15$ million & 30 & $\begin{array}{l}\text { Indie Rock then } \\
\text { Variety }\end{array}$ & Europe \\
\hline Indie-label 3 & $\begin{array}{l}\text { Distributed by } \\
\text { another } \\
\text { independent } \\
\text { record } \\
\text { company }\end{array}$ & unreported & 1 & Jazz & France \\
\hline
\end{tabular}

\subsection{Data Collection and Design}

Archives, interviews, internal documents, and reports from public institutions or phonographic associations represent the majority of our data collection. Direct observation was also used and formalized in several field notes reporting the internal organization and routines of the Sony-label. Archives were collected from the Sony Music France/US website and archive.org. We also consulted specialized websites and datasets of professional associations in the industry such as the International Federation of the Phonographic Industry (IFPI) and other local organizations such as the Syndicat National de l'Edition Phonographique (SNEP) and the Société Civile des Producteurs de Phonographe en France (SPPF). 
Semi directive interviews were our main source of data. These interviews enabled us to better understand the industry and the internal organization of the labels considered. Anonymous procedures were implemented from the beginning of our study. Because the music industry is a very competitive and socially interrelated sector, confidentiality was one of the most important issues in the guidelines of our protocol, which sometimes prevented direct exploitation of firms' statistics and official documents.

Table 2: Main characteristics of the interviews realized in the case study

\begin{tabular}{|l|l|l|l|}
\hline Status & Code & Duration & Interview method \\
\hline Director of Sony-label & Dir_Labmaj & $1 \mathrm{~h}$ 26min & $\begin{array}{l}\text { Interview conducted at the work } \\
\text { site }\end{array}$ \\
\hline Director of Indie-label 1 & Dir_indé1 & $1 \mathrm{~h} 40 \mathrm{~min}$ & $\begin{array}{l}\text { Interview conducted via } \\
\text { videoconference }\end{array}$ \\
\hline Director of Indie-label 2 & Dir_indé2 & $56 \mathrm{~min}$ & $\begin{array}{l}\text { Interview conducted } \\
\text { videoconference }\end{array}$ \\
\hline Director of Indie-label 3 & Dir_indé3 & $\begin{array}{l}\text { Interview conducted via email } \\
\text { exchange }\end{array}$ \\
\hline $\begin{array}{l}\text { Director of the } \\
\text { promotional department } \\
\text { of Sony-label }\end{array}$ & Dir_promo & $1 \mathrm{~h} 10 \mathrm{~min}$ & $\begin{array}{l}\text { Interview conducted at the work } \\
\text { site }\end{array}$ \\
\hline $\begin{array}{l}\text { Director of the creative } \\
\text { department of Sony-label }\end{array}$ & Dir_créa & $1 \mathrm{~h} 18 \mathrm{~min}$ & $\begin{array}{l}\text { Interview conducted at the work } \\
\text { site }\end{array}$ \\
\hline $\begin{array}{l}\text { Legal expert on business } \\
\text { affairs of Sony-label }\end{array}$ & Jur_business & $1 \mathrm{~h} 03 \mathrm{~min}$ & $\begin{array}{l}\text { Interview conducted at the work } \\
\text { site }\end{array}$ \\
\hline $\begin{array}{l}\text { Legal expert for Brand } \\
\text { partnership of Sony } \\
\text { Music Entertainment } \\
\text { France }\end{array}$ & Jur_brand & $42 \mathrm{~min}$ & $\begin{array}{l}\text { Interview conducted at the work } \\
\text { site }\end{array}$ \\
\hline $\begin{array}{l}\text { Director of the Supply } \\
\text { Chain of Sony Music } \\
\text { Entertainment France }\end{array}$ & Dir_supply & $59 \mathrm{~min}$ & $\begin{array}{l}\text { Interview conducted via phone } \\
\text { exchange }\end{array}$ \\
\hline
\end{tabular}

We conducted nine semi-directive interviews representing thirteen hours of recording (cf. Table 2). Due to timing issues, two interviews were carried out by videoconference. Another was carried out via email exchange over four consecutive days. As recommended by the literature, the interviews were recorded in such a way that all the dimensions of the speech were captured. All the interviews followed the same protocol based on a common framework with some arrangements and specific questions according to the status of the interviewee. Following the guidelines, interviews would open with a comparison between practices, resources, and strengths in the traditional era of the industry and today, and go on to questions and discussion focusing on the relationship between the firm and its environment.

Following the example of Yin (2003), we carried out data triangulation according to a dual scheme between primary (interviews, observations, artifacts etc.) and secondary sources (articles, reports etc.) to guarantee the validity of our data. When secondary empirical material was not formally confirmed by primary data, we consulted (by email) those able to provide 
relevant insight in order to reevaluate the validity of the material following an ad hoc method (Baumard and Ibert, 1999). We then proceeded to condense the data to facilitate their treatment. Interviews were reviewed in two stages: each recording was summarized in several sections and sub-sections based on content. We then proceeded to a systematic coding of the interviews into a generic scheme with other data sources.

\section{Sony Music Entertainment France: Case Study Results}

We now propose to test the analytical framework exposed in section 2 by analyzing the evolution of the intermediation of the music industry through the case study of Sony Music Entertainment. We first examine how the firm's internal resources can be designed or converted into transactional advantages over suppliers, customers, and ultimately competitors (section 4.1). Second, we explain how modularization plays a key role in the evolution of the Majors' transactional capability (section 4.2), in order to show how it allows the Majors to gain a competitive advantage through renewed intermediation in a 360-deal strategy (section $4.3)$.

\subsection{Building Transactional Capability Using Resource Renewal and Creation}

Sony Music Entertainment is no longer seen by its management as a record company but as a music-business company, whatever form this business takes. To achieve this progressive transformation, Sony Music Entertainment has redeployed its core strengths with new ones. The firm's core strengths can be grouped into three categories: recording and production of music content; promotion via traditional media; and physical distribution. These strengths are still crucial today but they are quite similar in any record company. Our results show, however, that these assets are valorized very differently today in Sony Music: the firm aims to exploit all complementarities (Brandenburger \& Nalebuff, 1995) that music can offer with other related products such as concerts, merchandising, advertising, etc. (cf. Figure 1). Whereas in the past these complementarities were occasional and entirely handled by other actors (management company, show producer, etc.), they are now optimized by the firm. As jur_business notes:

"We need artists to see us as a creator of opportunities and no longer as a record company. Part of our job is then to prospect and approach other firms and markets. I am a legal expert with an accounting report in my head."

We note that these capabilities have been developed from the firm's historical assets and properties as well as being acquired progressively over the past few years. First, Sony has some strategic resources that indie labels rarely possess, such as international names and a huge musical catalogue, due to its established position in the industry. These resources are used as bargaining tools to deal with suppliers in the best possible conditions. For example, 
big-name artists are essential for the main radio stations, allowing the firm to use their notoriety to impose less famous artists on the agenda. In the same way, the firm's large catalogue means it can negotiate much more profitable deals with online retailers than an indie label structure could do. Over the 2011-2013 period, streaming platform leader Spotify agreed to pay Sony Music a 9million dollar advance for the first year and 16 million for the second, with a 17.5 million advance for the optional third year ${ }^{3}$.

\section{Figure 1: Complementarities between Sony Music's traditional and new core strengths}

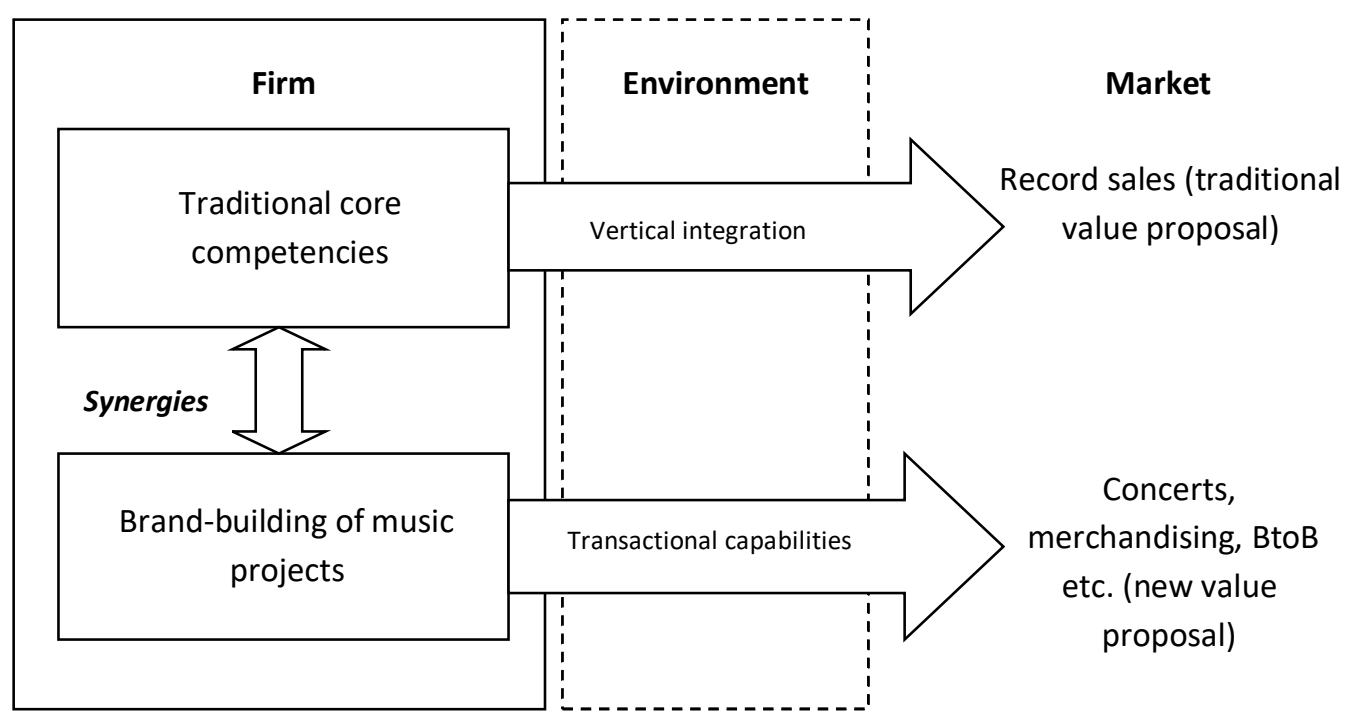

In addition, the total volume of the transaction for Sony Music Group is much higher compared with that of the indie labels. It obviously generates economies of scale and scope in transacting but also a higher frequency of social interaction and projects with suppliers raising the cost of opportunism. This is particularly true for art and craft companies providing packaging design, graphic charts, and pictures of music products. Majors such as Sony Music constitute important clients which help these companies build up their reputational resources. Their ability to transact repeatedly with these big record companies reduces their need to invest in bargaining.

In the same way, other Sony Music resources have been renewed with transactional ones via the accumulation of knowledge and data on the demand side. Among these resources, the supply chain asset can be considered to be highly strategic (Barney, 1991). Indeed, independent supply-chain infrastructure has been increasingly removed recently because of its low profitability in a context of a drastic reduction in size of the physical music market. This can be exemplified through the strategy of Sony Music Entertainment of purchasing independent label shares, such as in Atmosphérique in 2013, which has consequently renounced its own distribution system to survive. Costs have also increased

\footnotetext{
3 The Verge, http://www.theverge.com/2015/5/19/8621581/sony-music-spotify-contract, last consultation
} $05 / 05 / 2016$ 
because of the multiproduct base of the new business involving multichannel systems (digital chain, physic chain, derivative product chains etc.), which in turn multiply storage and disposal charges. This also requires very specific skilled employees in supply-chain management and logistics.

Our data suggest that this new trend is true for traditional channels, but more critically for digital supply chains. In this regard, the internet has transformed rather than removed barriers and costs due to the complexity and the diversity of interfaces, standards, audio formats, etc. Among these characteristics, metadata appear to be the trickiest to handle for companies. Metadata are a set of informational codes linked to musical content enabling its diffusion on digital retailer platforms. Metadata include basic information such as the name of the author, album title, ISRC code, and music style, but also contract rules and rights attached to the file embodied in digital devices. These data are one of the main sources of transaction cost in the digital market today; they require technical skills to understand digital standards and control illegal content on the internet. The Sony supply chain has recruited a team dedicated to setting up interfaces and protocols, checking the path and the cashflow generated by items. The team makes sure that digital activities conform to the contract terms of each file for each retailer and that rights holders receive corresponding revenue.

Thus, while the digital era has dramatically reduced storage costs, there is no guarantee that fixed costs and the human capabilities required to manage such complex channels are lower. This raises the question of the level of market concentration since distribution margins are very $l{ }^{4}$. It reinforces the fact that such capability is becoming more difficult to replicate than before, and increases the coopetition mechanisms between Majors and independents. Indeed, only Majors and some specialized distributors have such competencies. The three indie labels considered in our study do not have an in-house digital channel, which can generate coordination problems and technical slack as well as the costs charged by the external operator ${ }^{5}$.

The implementation of this multidimensional strategy has also required a new range of transactional capabilities in the aim to understand the diversity of consumer profiles and expectations. While in the past Sony Music was not really interested in consumer needs it is now directly involved in the sales relationship. Unlike the indie labels, Sony-label now manages direct-to-consumer marketing and selling: mailing lists, databases, newsletters, and satisfaction surveys to prospect consumer needs on a daily basis. This helps to confirm that Sony Music is developing transactional assets in order to increase its sales performance.

In the same way, Sony supply-chain staff have created routines aiming at capturing data on consumers: a Dashboard has been set up combining sales statistics, data left by users on social networks, and data collected by marketing and CRM supports. It creates intangible transactional assets that give some insight into what kind of music and products are

\footnotetext{
${ }^{4}$ A recent example of this concentration mechanism was the acquisition by French leader Believe Digital of the American company TuneCore in 2015.

${ }^{5}$ For example, indie-label 1 has to deal with the major Warner to distribute its physical output. This choice has been driven by the fact that Warner, thanks to economies of scale, proposes lower charges than any independent operator.
} 
appreciated by consumers according to parameters of demographic, gender, age, and location. The firm keeps track of what and how these consumers purchase products and then can benefit from this information to implement new successful musical items. This knowledge is used to discuss and enhance the label's chosen promotional strategy. Unlike online aggregator intermediaries, which focus only on the technical transaction cost, the Sony supply chain assumes a proactive role by proposing, readjusting, and checking the commercial evolution of a project. Regarding this fact, the competitive advantage linked to both physical and digital in-house supply chains is not only a matter of cost but, more importantly, one of knowledge.

This concern has been extended to the fan community monitored by community managers. The motivation of this integration is threefold. First the highly idiosyncratic aspect of the building process of any music branding requires a level of tacit knowledge which is easier to share inside the firm than it is outside. Moreover, the fact that communication on social networks is managed by employees permits a better social coordination between branding strategy and publications. Managers also have specific skills and tricks regarding how to handle interaction between fans and artists. This bilateral networking relationship creates an emotional commitment which contributes directly to turning fans into intensive buyers. As noted by Nusair et al. (2011), such commitment incites the consumer to be proactive in the brand building of the artist and raises his or her willingness to pay. Dir_labmaj frequently emphasized this new aspect of the business:

"We do not hesitate to use direct-to-consumer marketing today, although it didn't exist at all six years ago! I mean, we need to know fans and lure them because this is how we can make music valuable."

\subsection{Modularization as an Organizational Extension of Transactional Capabilities}

As we suggested earlier, the constant exchange that Sony Music has with the external world increases coordination costs inside the firm: the multiplicity of providers, projects, and interactions may generate organizational deficiencies (Penrose, 1959). A modularization system recently adopted by the label aims to deal precisely with this complex business expansion. This change was finalized in 2012, when promotion and communication services were redeployed into labels, whereas they had previously been centralized within the hierarchy of the Major. Dir_promo presents the main advantages of such a reorganization:

"It didn't work very well [before 2012]. With social network events and many other

releases you need to watch the stream otherwise your communication is just a big mess with all these things! It is easier to be integrated with the label. The whole process was vertical; today I work mutually with colleagues from other departments."

In this way, Sony Music hopes to handle a well-known dilemma in any creative industry: on the one hand, flexibility and decentralization are crucial to produce innovative and artistic output, but on the other hand, labels' teams have to produce managerial checks in order to maintain their coherence. In the case of Sony Music, labels are structured as follows: 
management decides on a branding strategy which is left to the interpretation of modules which divide it into several tasks and subprojects.

This structure is close to what Dubois \& Gadde (2002) describe. The firm is composed first of a "network within a network" articulated around a permanent set of actors performing its core competencies; and a second network which temporarily forms for each lateral project. The permanent network is characterized by standardization in terms of products and routines while the temporary network is characterized by a high degree of interdependency between different types of actor.

- First, the internal modularization level framed by departments within the label (communications, promotion, marketing, artistic, etc.) perform independent tasks which are, however, constantly revised by a progressive convergent integration of their respective outputs. This first modularization level is close to the overlapping model mentioned by Sanchez and Mahoney (1996) insofar as departments' output is collegially discussed every week in transversal meetings.

- Second, the external modularization level, in which tasks are split between the label's departments in modular subprojects based on coordination of the first level. This second level involves many types of actor both internal and external to the Major, such as its transversal services, freelancers, specialized firms, other entertainment industries, etc. Connection and exchange within these ad hoc modules are very intense, but the connection between modules is weak. This second level of modularization can be explained by the multidimensional aspect of the branding strategy.

- Ultimately, there is a third level of modularization that interacts with all Sony Music labels, which is directly handled by the central governance of the Major. These modules provide different types of service by intervening in the later stages of the labels' various projects.

The first level of modularization aims to produce a transactional music product, meaning a product that is both modular (divisible into sub-products and subprojects) and commercial (corresponding to a profitable demand). It consists of defining a general design, mixing both artistic and commercial assets to provide the second level with a branding prototype which modular subtasks and subprojects will be based on. This first arrangement is coordinated by standardized routines, and driven by a formal modular architecture corresponding to heads of department at the label. Standardized routines (weekly meetings, procedural discussions, etc.) are used to accelerate this brand-building process since it is partly non-decomposable (Hippel, 1988): artistic output impacts on how the branding should be conducted and vice versa.

This coordination can, however, generate many communication costs (Langlois, 2002) because every module needs to know sooner or later what the other modules are doing. To address these issues, Sony-label is framed by the label executive and Sony Music direction. The latter organize informal sharing sessions that guarantee strong convergence towards a shared vision that matches the corporate culture of the firm. Heads of both label and Major 
propagate a common language in the different departments in order to minimize communication costs (Langlois, 2002). At Sony Music, this "metalanguage" is driven by transactional properties: employees of the artistic department of Sony-label are characterized by a strong commercial background allowing them to understand the specific output from promotional and marketing departments such as global demand trends, marketable music styles, commercial techniques etc.

\section{Figure 2: Modular system organization at Sony-label and Sony Music}

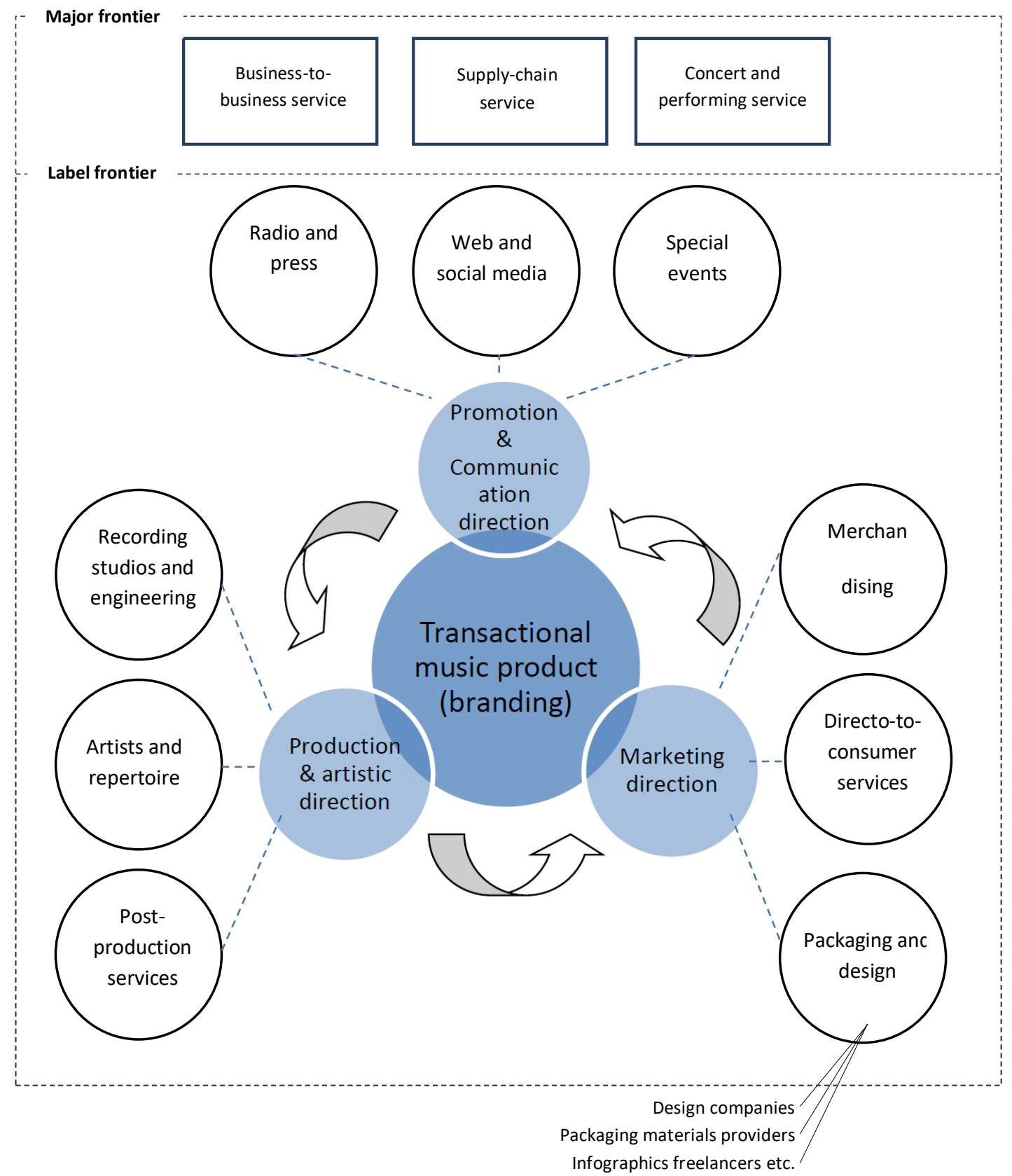


We should note that middle managers do not play the role of structural nodes between branding strategy and submodules; if the upstream coordination is well conducted, each team can easily provide relevant output without an intense communication cost due to the transactional nature of the music product. In this sense, the first level of modularization has two roles: first it must make understandable the idiosyncrasy of the music project in order to enable the second modular level to replicate its own specific knowledge coherently. Management's second role is to coordinate modules to achieve effective production, on-time delivery, and finally coherence with the branding strategy decided upstream. Consequently, this process allows creativity at the starting point of subprojects, but reduces creativity at the final stages as the branding strategy is being revised and consolidated by the management.

Our results show that the new organization is complementary to the development of transactional capability since such a process significantly enhances the transactional skills of employees involved in the later stages of production. Indeed, modularization favors commitment and trust since a limited number of people work together on a specific project. Such reliance between parties is commonly recognized as a positive feature for bargaining (Gulati \& Nickerson, 2004; Sako, 1991; Langfield-Smith \& Smith, 2003; Donada \& Nogatchewsky, 2006). For several activities, such as promotional work on radio, websites, or $\mathrm{TV}$, trust is reinforced by the fact that interactions are constantly repeated between the same groups of people (Gulati, 1995). Employees have personal connections with the media that sometimes go beyond professional needs. This offers opportunities to correct transaction disputes and reduce bargaining costs for future exchanges.

Such strategic commitment between the firm and suppliers is also an important basis for interfirm information sharing. It reduces asymmetries and transaction costs related to the specificity of assets because both parties transact with similar information. More importantly, such exchange favors knowledge transfer and creation between the label's employees and providers. This knowledge occurs first through conversations and operational tasks: daily activities tend to create a common cognitive framework between employees and providers which improves the implementation of subprojects at the local level. In other words, modularization creates specific knowledge by the fact that a limited number of people are working together on a specific project. Such an organization scheme favors the creation of reliance and the transfer of information, which is turned into capabilities for transacting with ad hoc external team members by the firm's employees.

We should also note that this social process implies transactional competencies which are quite different from what a TCT framework would recommend. The level of idiosyncrasy in music projects may be compared to Williamson's notion of asset specificity. According to the author, human assets are highly specific (Williamson, 1981), and require unified governance. This is not empirically confirmed in our results: as shown previously, the projectbased routines of the firm are structured via a flexible, modular structure involving both a firm's employees and providers.

One could argue that internalization would, however, allow Sony-label to profit directly from procedural efficiency and economies of scale. But such a view ignores the fact 
that music production has an idiosyncratic character involving tacit, social, and contextual skills (Polanyi, 1966) which are less appropriated to controls and checks. Employees, artists, and providers can respond damagingly to the overuse of formal procedures by provoking a spiral of distrust and self-seeking reaction (Ghoshal \& Moran, 1996; Wicks, Berman \& Jones, 1999). This idea can be clearly illustrated by the hierarchical pattern implemented by the production and artistic direction. The direction is well aware that it cannot directly intervene in the creative work of artists, technicians, and managers. Such formal control would disturb the cognitive framework built between teams. This framework depends, of course, not only on a project's branding strategy, but also on its musical style and maturity, the personality of the artist, and his or her needs, etc. Such appreciation is socially constructed from past experiences and past projects that make it necessarily specific and encapsulated in each module.

Regarding this fact, it can be observed that one of the most important differences between Sony-label and indie labels lies in this organizational and managerial feature. The managers of Indie-labels 1 and 3 have frequently insisted on the community aspect of their respective staff who share similar aesthetic values or ways of conducting business. In these firms, projects are made simultaneously by fewer people working with a common mental model. On the other hand, Sony Music Group and Sony-label do not have such a mental model because modules tend to develop their own views and practices which can be quite different from one another. This is precisely how the firm is able to develop transactional capability, because modularization encourages local and particular trust and information sharing which generates a higher level of relation-specific investment. This in turn increases interdependence and long-term relationships between Sony-label and suppliers (Heide and Miner, 1992; Parkhe, 1993). Thus, transaction costs can actually decrease despite the specificity of the assets.

\subsection{Transactional Capabilities as Competitive Advantage in Performing 360-Deal Strategy}

Transactional capabilities allow Sony Music to competitively perform its 360-deal approach by proposing a much more diverse and complex range of providers. In line with the work of Teece (2010), Sony Music Entertainment is now trying to focus on the very specific needs of consumers in order to satisfy unrequited demand. These needs are covered via many types of product, enabling the firm to proceed to price discrimination. In this regard, physical and digital supports are not seen as substitutable but constitute different markets for different types of consumer. In the physical market, the firm offers each release in a different format, ranging from basic CD to Deluxe and Vinyl editions including a high level of investment in design and packaging ${ }^{6}$. This segmentation is also realized in the digital market by offering different audio formats such as .mp3, .FLAC, .DSD, etc. In the same way, merchandising and many other derivative products constitute new ways to customize the offer. The firm is still pushing the boundaries to create new products and detect new clients from those of its

\footnotetext{
${ }^{6}$ Such assets increase the consumer's willingness to pay despite the fact that the music content is now largely available for free online. Increasing vinyl sales reflect this new trend - IFPI observes that this market grew 54.7 percent globally in 2014.
} 
competitors, and this process is fostered using both modularization and supply-chain resources.

Again, the complementarity between organization and transactional capability is confirmed. The propensity of the firm to extend its music intermediation to other markets is encouraged by transactional capabilities embodied in modules: through information sharing and encapsulated knowledge, employees discover new trends and practices from other related industries, which brings creative ideas for new business opportunities. In this regard, middle managers play a significant role in this innovative process: by monitoring corresponding ad hoc modules, they are able to detect and encourage best practices. By doing so, they manipulate modules members' sensing process by emphasizing the importance of some information or themes over others. This process accelerates the emergence of new ideas and the selection of the most profitable ones.

As we have seen above, front-line employees within modules, thanks to face-to-face interactions, are endowed with tacit knowledge making them progressively "expert" in their related markets. Consequently, the firm's boundaries expand in accordance with the absorptive capacities of the modular units towards other markets. The label focused first on close, related industries such as music publishing by dealing with Sony/ATV Company. In 2013, it formed a partnership with global merchandising leader BandMech. The label is now thinking about a deal with the French book publisher Gallimard to make comics and novels based on its recent musical repertoire. This latter example is a good illustration of this learning and innovative process. Employees from Sony-label marketing modules were initially less familiar with the book publishing industry, but are now more and more inclined to develop derivative goods with this market.

Transactional capabilities also favor better coordination between the different elements of the 360-deal value proposal. As mentioned, music is a rapid-life cycle product which requires a high level of coordination. Music management is dedicated to guaranteeing such coordination by implementing deadlines and planning procedures. However, the fact that Sony Music Entertainment owns its own supply chain gives significant flexibility. This allows the synchronization of promotional tasks, music releases, and derivative product distribution. When a music product is in the process of becoming a hit, other associated products must be conceived and distributed very quickly because of their dependent life cycle. This allows the firm to ensure that each subproject is as close as possible to this lifetime in order to transact all products at the optimal moment. Such coordination is not always possible for independent labels since their release agenda is partly controlled by the distributor.

Similarly, transactional capability provides Sony Music with a competitive advantage over its independent competitors in the identification process of new corporate clients: not only are consumer and fan data collected from the supply chain o analyzed to better react to music user demand, but they are also turned into transactional assets for opening business with corporate clients (such as sponsorship, endorsements, synchronization, etc.). Indeed, Sony Music has initiated a business-to-business team to conclude deals with other companies. In a context of weak IP effectivity, such cooperating clients constitute an increasingly 
profitable market for labels. This new market has required various legal capabilities to reduce transaction costs associated with contract arrangements.

Our results show that Indie-labels 1 and 2 have also tried to offer products for corporate clients in order to expand their image and entice new consumers that would otherwise be out of their scope. But once again, the transactional advantage of Sony Music compared with its independent competitors comes from the knowledge that the firm is able to absorb through its data management. Endowed with data, Sony Music can detect the main consumption practices and characteristics of an artist's fans. It is then able to provide a tailormade product by associating the artist's brand with the relevant client's product into the relevant setup (cobranding, events, product placement, music themes for TV ads, etc.). These results are consistent with the recent literature which has demonstrated that the acquisition of an effective supply-chain management system contributes directly to developing relational capabilities and innovation by reducing purchasing costs, making higher-quality products, encouraging supplier or client integration, increasing the speed of delivery, and increasing flexibility and knowledge (Beske, 2012; Delbufalo, 2012; Prajogo et al., 2012).

Recent investments made by the firm confirm this emerging data-centered approach: Sony is a shareholder of streaming leader Spotify, and bought a 9-million-dollar stake, along with Warner and Universal Music, in music-identification application Shazam ${ }^{7}$ in 2014 with the aim of improving the digital marketing of artists. Sony Music is now investing in technical tools to collect and analyze information about consumers and user profiles. The huge amount of information involved requires new investment and skills which are being realized jointly with firms specialized in Big Data treatment.

The internalization of gig promoter Arachnée was driven by the same motivations. Of course, the spectacular growth of this market has pushed Sony Music to vertically integrate show facilities to align profit incentives and diminish transaction costs. This new focus on music performance is also materialized through various partnerships with festivals: in 2014, Sony Music become producer of the We Love Green festival. A legal and technical module support is entirely dedicated to setting up tours and concerts in order to better capture the economic value of live music. But, more importantly, this new resource provides information about consumer practices and tastes. As for the supply chain, the fact that Sony Music owns concert facilities helps to guarantee control of the agenda. It also constitutes a test for new artists to meet their audience, thereby giving a general idea of the success of a branding strategy and useful insight to help readjust this in the case of failure.

"Concerts are just the very first step after CD sales. When an artist starts to sell records Dir_labmaj

and perform well you may have something which is interesting to exploit in other fields."

These last points illustrate the high level of complementarity between the new value proposition and the traditional resources of the firm: traditional channels which are focused on consumers generate a range of data which are in turn converted into transactional insight to perform 360 deals. This allows Sony Music Entertainment to capture new aspects of the 
economic value of the musical content while preserving its music producer core competencies. This emphasis on knowledge creation and flow in our analysis emphasizes the fact that the idea of transactional capability includes an economic reality which is more complete than it is on the consumer-oriented side, such as marketing or promotional tasks. It investigates the entire proactive role that the firm adopts in order to transact with the market; including its capacity to renew its resources to better satisfy usual and new types of client. As Dir_labmaj highlights:

"If we are still here it's because we are multiservice. This is a key service that we give to artists: today nobody can control music so we have to offer something that we can control with external or in-house partners such as concerts."

\section{Conclusion}

The difficulty of capturing economic value from records sales has made the music business much more complex than it was before, with a larger variety of potential sources of revenue combined with a larger variety of intermediation roles and related required assets. In the case of the Majors, this complexity is handled by the development of capabilities which increase the efficiency and quality of their interactions with the two sides of the market.

More precisely, we have tried to provide an explanation for the resilience of the Majors amid the tremendous changes affecting the music industry from the mid-2000s to the market downturn of 2015/2016. Three dimensions have emerged from our analysis.

First, Majors still preserve a competitive advantage in music market intermediation by successfully performing a "360 deal approach". This new business model aims to exploit synergistic relationships between a growing number of sectors, industries, and projects.

By providing insight into both the supply and the demand side, we have stressed the fact that Sony Music's performance is not only due to its ability to sell finished products but is also linked to its ability to order and purchase relevant inputs especially when these are fairly distant from the firm's resources. Such transversal analysis underlines the synergistic relationship between knowledge flow from the demand and the supply side: permanent connection with providers enables Sony Music to absorb some insight into related industries and offer opportunities to develop new products. At the same time, the collection of data on sales performance and consumer profiles allows the firm to check the validity of the multiproduct strategy. In this regard, the two-sided aspect of transactional capability underlines the mutual impact of pre- and post-production knowledge flow.

Second, in order to develop their new "360 deal" strategy, Majors change their music market intermediation role by rearranging and valorizing their traditional strategic resources with transactional capabilities.

This complex intermediary role cannot be endorsed by aggregators since they are exclusively and technically dedicated to reducing transaction costs between subscribers and online retailers in the digital music market. On the other side, independent labels do not have 
the very strategic resources that permit the development of sustainable transactional capability. Indeed, not all firms are able to earn systematically relational rents. Majors have historically developed strategic resources that are considered to be less important today because of digitalization (a huge back catalogue related to copyright duration, CD-ROM supply chain, recording facilities, etc.). However, it is precisely the role of transactional assets to augment and extend the existing resources of the firm with the resources of its partners. Only Majors can perform this set of complex and diverse assets efficiently thanks to the transactional combination of their strategic resources.

Third, Majors develop and sustain transactional capability by arranging their business organization into a modular system.

A modular system saves management resources by enabling the decomposition of a complex system into simpler sub-systems (Koppl \& Langlois, 2000). It leads to a separation of learning about the architecture of the system from learning about the features of the modules. This dichotomy allows an increase of diversity generated by a recombination of the modules and reinforces the capabilities of the whole system to valorize faster innovations and knowledge generated locally (Bureth \& Pénin, 2007).

Some contributions had already underlined the crucial role of effective governance mechanisms in optimizing relational assets. For instance, Donada \& Nogatchewsky (2008) show that modularization favors relational capabilities concerning the evaluation and selection of suppliers. However, this literature stays focused on the supplier side and thus does not provide an understanding of the intermediation process of firms that connects both sides of the market.

Beyond this, we suggest that modularity is also a strategic means of enhancing capabilities thanks to its propensity to reduce both internal and external transaction costs. Indeed, modularity increases transaction performance by involving the provider directly in effective and frequent interaction within modular units (Dyer, 1996, Dyer \& Nobeoka, 2000, Danoda et al., 2016). Modularity is then crucial to understanding how the firm can actively develop and sustain transactional capability. In other words, modularity allows a rationalization of the management of diverse or complex transactional activities - as a Major's music business tends to be.

Will this resilience of the Majors be robust in the face of the most recent and current evolution of the music industry and market? In 2015, global music revenue increased for the first time in the nearly two decades; in 2015/16 digital revenue overtook physical income, and in 2016 the threshold of 100 million worldwide subscribers to paid streaming services was reached $^{8}$. However, according to MIDIA Research, in 2016, the Majors' oligopoly still held 68.7 percent, 72.5 percent, 71.7 percent 61.8 percent and 49.9 percent of the recorded music,

\footnotetext{
${ }^{8}$ https://insights.midem.com/tech/beyond-streaming-law-tech-andentertainment/?utm_source=clnr\&utm_medium=md_emailing\&utm_campaign=midem2017_content_newsletter $-15052017 \&$ ione_extid=0032000001MqJ6hAAF, last consultation 04/07/2017
} 
download, streaming, physical and publishing markets respectively ${ }^{9}$. On the one hand, the digital market has now reached 50 percent of total recorded music revenue, with an increasing share of already almost 60 percent from streaming. In those markets, Majors are facing not only Apple (which now challenges Spotify as market leader ${ }^{10}$ ) but also Google via YouTube (music video). On the other hand, a new wave of potential music-supporting technologies is coming on the scene (augmented and virtual reality, blockchain, etc.). In between, social network actors such as Facebook are showing growing interest in music-related activity ${ }^{11}$. In this context, the way the Majors are adapting/will surely again adapt their networks of value creation and capture with renewed transactional capability of course remains to be analyzed.

From a more theoretical perspective, we have tried to further explore and illustrate with concrete examples, the concept of transactional capability, which is still only emerging. Above all, we have provided more elements to justify the role of transactional capability as a bridge between TCT and KBV, and we have shown that it must be viewed in close connection with a firm's strategy and mode of organization. In addition, in our specific case, the original role of modularity has been widely investigated.

Finally, whether the analysis developed in this paper could be applied to other sectors remains an open question. Of course, the fact that the music industry is structured by the copyright system consolidates the power of the market's historical actors. It facilitates the ability of the firm to capture an intermediation rent from other related markets, but it does not explain how these interactions are successfully detected, performed, and sustained. On this point, our case study has shown that transaction cost properties can be modified by internal assets (such as social interaction with suppliers, data management skills, commercial background, etc.). Different appropriation regimes could then lead to different types and usage of transactional capability, as well as to different combinations between them, strategy, and mode of organization. Following the line initiated by the seminal paper by Teece (1986), different configurations in different sectors could also be explored in this respect, taking into account appropriability of regime, pre-paradigmatic versus the dominant design phase, etc.

However, we believe that the case of the music Majors could serve as an archetype for new forms of organization in other creative industries, or even for more traditional industries, to the extent that it highlights a new field of deployment for transactional capability. In a "traditional" view of the search for complementary assets (of which Teece 1986 is emblematic), these are of various natures (technology, service, distribution, manufacturing, etc) and are integrated or contracted out in order to generate revenue from sales of a given product (or line of product). In the creative industries (for instance following the Motley Crew principle), usually "production requires diversely skilled inputs, non-uniformed/undisciplined.

\footnotetext{
${ }^{9}$ https://musicindustryblog.wordpress.com/2017/02/26/global-recorded-market-music-market-shares-2016/, last consultation 04/07/2017

${ }^{10} \mathrm{http}: / / w w w . h y p e b o t . c o m / h y p e b o t / 2017 / 04 /$ at-32-million-subscribers-apple-music-challenges-spotify-asstreaming-leader.html, last consultation 04/07/2017

${ }^{11} \mathrm{http}: / / \mathrm{www}$.dancingastronaut.com/2017/02/facebook-attempting-enter-music-industry/, last consultation $04 / 07 / 2017$
} 
Each skilled input must be present and perform at some minimum level to produce a valuable outcome" (Caves, 2000, p. 5-6). Via different internal organizations or interaction with the local environment, these complementary assets are also combined to give birth to one product or line of a product which can itself be seen as a mix-product (see the typical example of movies or more recently video games). In both cases, one could consider transactional capability in order to combine these different categories of asset most efficiently.

In the case of the music industry, 360-deal strategy, the challenge is to get access, to combine, and exploit a variety of products and services of very different natures, or, put another way, to exploit the multiple possible experiences related to an artist and/or piece of music. Coming back to the theoretical challenge, it is perhaps in this third type of context that the concept of transactional capability is the most promising, not only in its application to other sectors than the music industry, but also in its way of being more highly defined from a theoretical perspective.

\section{Bibliography:}

Albarello, L. (2011), Choisir l'Etude de Cas Comme Méthode de Recherche, De Boeck Edition.

Alexander, P. (1994), "Entry Barriers, Release Behavior, and Multi-Product Firms in the Music Recording Industry", Review of Industrial Organization, Volume 9, 85-98.

Alexander, P. J. (2002), "Peer-to-Peer File Sharing: The Case of the Music Recording Industry", Review of Industrial Organization 20: 151-161.

Amit, Z., Zott, C. (2005), How Do Firm Resources Affect Transaction Governance? Working paper series, INSEAD-Wharton Alliance Center for Research \& Development.

Anderson, C. (2004), “The Long Tail”, Wired.

Argyres, N., Liebeskind, J. (1999), "Contractual Commitments, Bargaining Power, and Governance Inseparability: Incorporating History into Transaction Cost Theory”, Academy of Managerial Review 24 (1), 49-63.

Barbier, J. Y., Calvez, V., Poux, M. (2008), « Quelles reconfigurations de la chaîne de valeur et du management de la création dans l'industrie musicale? " SEES / REVUE ECONOMIQUE ET SOCIALE, no. 1, mars 2008.

Barney, J. B. (1991), "Firm Resources and Sustained Competitive Advantage", Journal of Management, 11, 3, 656-665.

Barney, J., Wright, M., David, J., Ketchen, J. (2001), "The Resource-Based View of the Firm:

Ten Years after 1991”, Journal of Management 27, 625-641.

Baumard, P., Ibert, J. (1999), «Quelles Approches Avec Quelles Données?» R. A. T. e. coll. (Ed.), Méthodes De Recherche En Management. Paris: Dunod. 
Becker, G. (1962), "Irrational Behavior and Economic Theory”, Journal of Political Economy $70(1), 1-13$.

Benkler, Y. (2006), The Wealth of Networks: How Social Production Transforms Markets and Freedom, Yale University Press, London.

Bernardo, F. (2013), "Disintermediation Effects in the Music Business - A Return To Old Times?" Music Business Research.

Beske, P. (2012), "Dynamic Capabilities and Sustainable Supply Chain Management", International Journal of Physical Distribution \& Logistics Management 42(4): 372-87.

Beuscart, J. M. (2007), « Les transformations de l'intermédiation musicale, la construction de l'offre commercial de musique en ligne en France », La Découverte, Réseaux, ${ }^{\circ} 141$ 142 pp.143 à 176.

Blanc, A., Huault, I. (2010), « Reproduction De L'ordre Institutionnel Face À L'incertitude. Le Rôle Du Discours Des Majors Dans L'industrie Musicale », Revue française de gestion, 203(86-99).

Brandenburger, A. M., Nalebuff, B. J.(1995), "The Right Game: Use Game Theory to Shape Strategy", Harvard Business Review, July-August: 57-71.

Bureth, A., Pénin, J. (2007) "Modular Innovations and Distributed Processes, the Case of Genetically Engineered Vaccines", EJESS - 20/2007. Knowledge and Innovative Activities, pages 251 to 274 .

Casadesus-Masanell, R., Hervas-Drane, A. (2008), Peer-to-Peer File Sharing and the Market for Digital Information Goods.

Caves, J. E. (2000), Creative Industries: Contracts between Art and Commerce. Cambridge, MA: Harvard University Press.

Chandler, A.D. (1992), "Organizational Capabilities and the Economic History of the Industrial Enterprise", Journal of Economic Perspectives 6 (3), 79-100.

Chircu, A. M., Kauffman, R. J. (1999), "Strategies for Internet Middlemen In The Intermediation/Disintermediation/Reintermediation Cycle", Electronic Markets - The International Journal of Electronic Commerce and Business Media, 9, 2, pp. 109-117.

Coase, R. (1937), “The Nature of the Firm”, Economica, Vol 4, №16, p.386-405.

Cohendet, P., Llerena, P. (2005), "A Dual Theory of the Firm Between Transactions and Competences: Conceptual Analysis and Empirical Considerations", Revue d'économie industrielle, vol. 110, 2e trimestre 2005. pp. 175-198.

Curien, N., Moreau, F. (2006), L'industrie Du Disque: La découverte.

Delbufalo, E. (2012), "Outcomes of Inter-Organizational Trust in Supply Chain Relationships: A Systematic Literature Review and a Meta-analysis of the Empirical Evidence", Supply Chain Management: An International Journal 17(4): 377-402. 
Donada, C., Nogatchewsky, G. (2006), "Vassal or Lord Buyers: How to Exert Management Control in Asymmetric Interfirm Transactional Relationships?", Management Accounting Research, 17(3), 259-287.

Donada, C., Nogatchewsky, G. (2008), "Partenariat, vassalité, marché et seigneurie: 4 configurations de contrôle client-fournisseur", Comptabilité Contrôle Audit 14 (1): 145168 .

Donada, C., Nogatchewsky, G., Pezet, A. (2016), "Understanding the Relational Dynamic Capability-Building Process", Strategic Organization, Vol. 14(é) 93-117.

Du Gay, P., Salaman, G., Rees, B. (1996), "The Conduct of Management and the Management of Conduct: Contemporary Managerial Discourse and the Constitution of the 'Competent' Manager", Journal of Management Studies 33 (3), 263-282.

Dubois, A., Gadde, L-E. (2002), "The Construction Industry as a Loosely Coupled System: Implications for Productivity and Innovation", Construction Management and Economics, 20, 7, 621-631.

Dyer, J. H. (1996), "Specialized Supplier Networks as a Source of Competitive Advantage: Evidence from the Auto Industry", Strategic Management Journal, 17(4), 271-291.

Dyer, J. H. and Nobeoka, K. (2000), "Creating and Managing a High-Performance Knowledge-Sharing Network: The Toyota Case", Strategic Management Journal, 21(Special Issue): 245-367

Dyer, J. H., Singh, H. (1998), "The Relational View: Cooperative Strategy and Sources of Interorganizational Competitive Advantage", Academy of Management Review 23(4): 660-79.

Dyer, J., Kale, P. (2007), "Relational Capabilities: Drivers and Implications", in C. E. Helfat, S. Finkelstein, W. Mitchell, H. Singh, D. Teece and S. G. Winter (eds), Dynamic Capabilities: Understanding Strategic Change in Organizations, pp. 65-79. Malden, MA: Blackwell Publishing.

Eisenhardt, K. M. (1989), "Building Theories from Case Study Research", Academy of Management Review, 1989, Vol. 14 NO. 4, 532-550.

Eisenhardt, K. M., Martin, J. A. (2000), “Dynamic Capabilities: What Are They?”, Strategic Management Journal, 21(10-11): 1105-21.

Gander, J., Haberberg, L. A., Rieple, A. (2007), "A Pradox of Alliance Management: Resource Contamination in the Recorded Music Industry", Journal of Organizational Behavior 28: 607-624 Gauntlett.

Ghoshal, S. \& Moran, P. (1996) "Bad for Practice: A Critique of the Transaction Cost Theory, Academy of Management Review Vol. 21 No.1

Gulati, R. (1995) "Does Familiarity Breed Trust? The Implications of Repeated Transactions", Academy of Management Journal Vol. 38 Issue.1 
Gulati, R., \& Nickerson, J. A. (2004), "Inter-Organizational Trust, Governance Choice, and Exchange Performance", Working Paper, Northwestern University, 14 September 2004.

Heide, J. B., Miner, A. (1992), "The Shadow of the Future: Effects of Anticipated Interaction and Frequency of Contact on Buyer-Seller Cooperation", Academy of Management Journal, 35(2), pp. 265-291.

Hippel, Von, E. (1988): The Sources of Innovation, New York: Oxford University press.

Hracs, B. (2012), "A Creative Industry in Transition: The Rise of Digitally Driven Independent Music Production", Growth and Change, vol. 43 n3 pp. 442-461.

Ireland, R. D., Hitt, M. A. Vaidyanath, D. (2002), "Alliance Management as a Source of Competitive Advantage", Journal of Management 28(3): 413-46.

Jacobides, M., Winter, S. (2005), “The Co-Evolution of Capabilities and Transaction Costs: Explaining the Institutional Structure of Production", Strategic Managerial Journal 26 (5), 395-413.

Kale, P., Dyer, J. H., Singh, H. (2002), “Alliance Capability, Stock Market Response, and Long-Term Alliance Success: The Role of the Alliance Function", Strategic Management Journal, 23(8): 747-67.

Katz, J. (1984), Domestic Technological Innovations and Dynamic Comparative Advantage, Journal of Development Economics 16 (1-2), 13-37.

Koppl, R., Langlois R. N. (2000), "Embeddedness, Organizations, and Language Games", Paper for presentation at the MPI/LINK Workshop on Cognition and Evolution in the Theory of the Firm, September 25-27,2000, Jena, Germany, and at the SCANCOR Conference on "Crossing Boundaries: Economics, Sociology and Organization Theory”, Stanford, California.

Krattenmaker, T.G., \& Salop, S.C. (1986), "Anticompetitive Exclusion: Raising Rivals' Cost to Achieve Power over Price", The Yale Law Journal, volume 96, Number 2, December, p.209-292.

Lall, S. (1992), "Technological Capabilities and Industrialization",. World Development, v. 20, n. 2, p. 165-186.

Langfield-Smith, K., \& Smith, D. (2003), "Management Control Systems and Trust in Outsourcing Relationships”, Management Accounting Research, 14(3), 281-307.

Langlois, R. N. (2002), "Modularity in Technology and Organization", Journal of Economic Behavior \& Organization, vol. 49, p. 19-37.

Langlois, R., Foss, N. (1999), "Capabilities and Governance: The Rebirth Production in the Theory of Economic Organization", KYKLOS 52 (2), 201-218.

Lebrun, B. (2006) « Majors et labels indépendants », Vingtième Siècle. Revue d'histoire 4 (no 92), p. 33-45. 
Leyshon, A. (2009), "The Software Slump?: Digital Music the Democratisation of Technology, and the Decline of the Recording Studio Sector Within the Musical Economy”, Environment and Planning A 2009, volume 41, pages 1309-1331.

Marshall, L. (2013), “The 360 Deal and the 'New' Music Industry”, European Journal of Cultural Studies, February 2013 16: 77-99.

Miller, J., Roth, A. (1994), “A Taxonomy of Manufacturing Strategies”, Management Science 40 (3), 285-304.

Moyon, E., Lecocq, X. (2007), La dynamique des réponses stratégiques des Majors au changement institutionnel dans l'industrie de la musique, Document de travail du LEM, CIDEF-AFI, Université Laval, Québec.

Moyon, E., Lecocq, X. (2013), Adopting a Business Model View to Study Industry Change: The Case of the French Record Industry, Communication présentée à la XXIIème conférence de l'AIMS, Clermont-Ferrand.

Nelson, P. (1970), "Information and Consumer Behaviour", Journal of Political Economy, vol. 78, pp. 311-329.

Nusair, K., Parsa. H. G., Copanoglu. C. (2011), "Building a Model of Commitment for Generation Y: An Empirical Study on E-Travel Retailers", Tourism Management, vol. $32, n^{\circ} 4$.

Ordanini, A. Miceli, L., Pizzetti, M. Parasuraman, A. (2009) "Crowdfunding: Transforming Customers into Investors Through Innovative Service Platforms", Journal of Service Management, vol. 22, no. 4, pp. 443-470.

Parkhe, A. (1993), "Strategic Alliance Structuring: A Game Theoretic and Transaction Cost Examination of Interfirm Cooperation", Academy of Management Journal, 36(4), pp. 794-829.

Patel, P., Pavitt, K. (1997), “The Technological Competencies of the World's Largest Firms: Complex and Path-Dependent, but not Much Variety", Research Policy 26 (2), 141-156.

Penrose, E. (1959), The Theory of the Growth of the Firm, Oxford University Press, New York. 272 p.

Polanyi, M. (1966) The Tacit Dimension, New York: Doubleday.

Poppo, L., Zenger, T., (2002), "Do Formal Contracts and Relational Governance Function as Substitutes or Complements?”, Strategic Managerial Journal 23 (8), 707-725

Prahalad, C., Hamel G. (1990), "The Core Competence of the Corporation", Harvard Business Review 68 (3),79-91.

Prajogo, D., Chowdhury, M., Yeung, A. and Cheng, T. (2012), "The Relationship between Supplier Management and Firm's Operational Performance: A Multi-Dimensional Perspective", International Journal of Production Economics 136(1): 123-30

Riordan, M., Williamson, O. (1985), “Asset Specificity and Economic Organization”, International Journal of Industrial Organization, vol. 3, pp. 365-378. 
Rupp, P., Estier, T. (2002), “A Model for a Better Understanding of the Digital Distribution of Music in a Peer-to-Peer Environment", Proceedings of the 36th Hawaii International Conference on System Sciences.

Sako, M. (1991), “'The Role of 'Trust' in Japanese Buyer-Supplier Relationships'”, Ricerche Economiche, 45(2-3), pp. 449-474.

Sanchez, R., Mahoney J. (1996), "Modularity, Flexibility, and Knowledge Management in Product and Organization Design", Strategic Management Journal, vol. 17, Winter Special Issue, p. 63-76.

Schilke, O. (2014), "On the Contingent Value of Dynamic Capabilities for Competitive Advantage: The Nonlinear Moderating Effect of Environmental Dynamism”, Strategic Management Journal, 35(2), 179-203.

Schreiner, M., Kale, P. and Corsten, D. (2009), "What Really Is Alliance Management Capability and How Does it Impact Alliance Outcomes and Success?", Strategic Management Journal 30(13): 1395-419.

Selznick, P. (1957), Leadership in Administration: A Sociological Interpretation, University of California Press, Berkeley and Los Angeles.

Sen, A. (2010), "Music in the Digital Age: Musicians and Fans Around the World Come Together on the Net", Global Media Journal, Spring 2010, Volume 9, Issue 16.

Simon, H. A. (1962), "The Architecture of Complexity: Hierarchic Systems", Proceedings of the American Philosophical Society, Vol. 106, No. 6, December 1962, p. 941-73.

Skinner, W., (1969), "Manufacturing: Missing Link in Corporate Strategy", Harvard Business Review 47 (3), 136-145.

SNEP, (2010), L'Economie de la Production Musicale, Edition 2010, Syndicat National de l'Edition Phonographique.

Stamp, G. (1981), "Levels and Types of Managerial Capability", Journal of Managerial Studies 18 (3), 277-298.

Teece, D.J. (1986) "Profiting from Technological Innovation: Implications for Integration, Collaboration, Licensing and Public Policy", Research Policy 15(6), 285-305.

Teece, D. J. (2010) "Business Models, Business Strategy and Innovation”, Long Range Planning 43, 172-194.

Teece, D. J., Pisano, G. and Shuen, A. (1997), "Dynamic Capabilities and Strategic Management”, Strategic Management Journal, 18(7): 509-33.

Tello-Gamarra, J., Zawislak, P. A. (2013), “Transactional Capability: Innovation's Missing Link", Journal of Economics, Finance and Administrative Science, 2-8. 
Van der Meer-Kooistra, J. and Vosselman, E. G. (2000), "Management Control of Interfirm Transactional Relationships: The Case of Industrial Renovation and Maintenance", Accounting, Organizations and Society 25(1): 51-77.

Waldfogel, J. (2012), "Music Piracy and its Effects on Demand Supply, and Welfare", Innovation Policy and the Economy, Volume 12, p.91-109.

Wicks, A., Berman, S., Jones, T. (1999), "The Structure of Optimal Trust: Moral and Strategic Implications", Academy of Management Review. Vol. 24, No.1, 99 -116.

Wikström, P. (2009), The Music Industry: Music in the Cloud, Cambridge: Polity Press; 1 edition.

Williamson, O. (1981), "The Economics of Organisation: The Transaction Cost Approach", American Journal of Sociology Vol. 87 Issue 3 Nov 548-57.

Williamson, O. (1985), The Economic Institutions of Capitalism - Firms, Markets and Relational Contracting, New York, The Free Press, 450 p.

Williamson, O., (1999), "Strategic Research: Governance and Competence", Strategic Management Journal 20 (12), 1087-1108.

Williamson, O.E. (1975), Markets and Hierarchies: A Study in the Internal Organizations, Macmillan, New York.

Winter, C. (2012), "How Media Prosumers Contribute to Social Innovation in Today's New Networked Music Culture and Economy", International Journal of Music Business Research, vol. 1, no. 2, pp. 46-73.

Yin, R. K. (2003), Case Study Research: Design and Methods (3rd Edition). California: Sage Publications.

Zander, U., Kogut, B. (1995), "Knowledge and Speed of The Transfer and Imitation of Organizational Capabilities: And Empirical Test”, Organization Science 6 (1), 76-92.

Zawislak, P., Alves, A., Tello-Gamarra, J., Barbieux, D., Reichert, F., (2012), "Innovation Capability: From Technology Development to Transaction Capability", Journal of Technology Management \& Innovation 7 (2), 14-27. 